therapeutic dose that we used produced a striking increase in heart rate in our normal subjects that was maximal in combined hypoxia and hypercapnia. This increased heart rate was associated in all subjects with appreciable palpitations, flushing, and minimal tremor.

Undoubtedly intravenous infusions of salbutamol, in the dose which we have studied, may produce bronchodilatation in patients with stable ${ }^{14}$ and severe ${ }^{15}$ asthma. It is unlikely that the effects on the chemical control of ventilation which we have shown will be of much benefit when salbutamol is used in asthma, for in such patients the ventilatory drive is already considerably increased. The drug may be valuable in increasing ventilatory drive in bronchitic patients with the hypercapnia of chronic ventilatory failure. ${ }^{9} \mathrm{We}$ are concerned at the pronounced tachycardia that occurred during salbutamol infusion for serious cardiac dysrhythmias may result ${ }^{23}{ }^{24}$ when tachycardia, hypoxia, and acidosis are present, as they commonly are in status asthmaticus. The hypokalaemic effect of salbutamol is equally disturbing, for considerable falls in plasma potassium may also be associated with cardiac dysrhythmias in digitalised patients. ${ }^{25}$ We therefore suggest that if intravenous infusion of salbutamol is used in the management of severe asthma both the plasma potassium and the electrocardiogram should be carefully monitored.

We thank our volunteers, Sister McLay and staff nurses for nursing supervision, Mrs R Adams and Mr R Johnstone for technical help, Misses M Cumming and L Graham for secretarial help, and Professor K W Donald for laboratory facilities. We also thank Dr A T Lambie. for advising on the urinary study and Professor J A Strong and Mrs I M Nairn for performing the insulin assays.
Requests for reprints should be addressed to Dr A G Leitch, Department of Medicine, Royal Infirmary, Edinburgh EH3 9YW.

\section{References}

1 Young, I M, fournal of Physiology, 1957, 137, 374.

2 Whelan, R F, and Young, I M, British fournal of Pharmacology, 1953, 8, 98.

${ }^{3}$ Heistad, D D, et al, fournal of Clinical Investigation, 1972, 51, 1469.

4 Stone, D J, et al, Fournal of Applied Physiology, 1973, 34, 619.

5 Joels, N, and White, H, fournal of Physiology, 1968, 197, 1.

${ }^{6}$ Cunningham, D J C, et al, Annals of the New York Academy of Sciences, $1963,109,756$.

7 Cunningham, D J C, Lloyd, B B, and Patrick, J M, Fournal of Physiology, 1963, 165, 45P.

${ }^{8}$ Rebuck, A S, and Read, D J C, Clinical Science, 1971, 41, 13.

${ }^{9}$ Flenley, D C, Franklin, D H, and Millar, J S, Clinical Science, 1970, 38, 503.

${ }^{10}$ Leitch, A G, Clancy, L J, and Flenley, D C, Clinical Science and Molecular Medicine, 1974, 47, 377.

${ }^{11}$ Cunningham, D J C, et al, Quarterly fournal of Experimental Physiology, $1961,46,323$

${ }^{12}$ Hales, C N, and Randle, P J, Biochemical fournal, 1963, 88, 137.

13 Warrell, D A, et al, British Medical fournal, 1970, 1, 65.

${ }^{14}$ Paterson, J W, Courtenay-Evans, R J, and Prime, F J, British fournal of Diseases of the Chest, 1971, 65, 21.

${ }^{15}$ Marlin, G E, and Turner, P, British Medical fournal, 1975, 2, 715.

${ }_{17}^{16}$ Davis, $\mathrm{H} \mathrm{J}$, personal communication.

${ }_{17}$ Lefrancois, R, et al, Respiration Physiology, 1972, 14, 296.

${ }^{18}$ Lundholm, L, Svedmyr, N, Acta Physiologica Scandanavica, 1966, 67, 65.

${ }^{19}$ Coles, D R, et al, British fournal of Pharmacology, 1956, 11, 346.

${ }^{20}$ Goldring, R M, et al, fournal of Clinical Investigation, 1968, 47, 188

${ }^{21}$ Imura, H, et al, fournal of Clinical Investigation, 1971, 50, 1069.

22 Porte, D, Diabetes, 1967, 16, 150.

${ }^{23}$ Collins, J M, et al, British fournal of Pharmacology, 1969, 36, 35.

${ }^{24}$ Shanks, R G, and Swanton, J G, Proceedings of the European Society for the Study of Drug Toxicity, 1971, 12, 147.

${ }^{25}$ Lown, B, Advances in Internal Medicine, 1956, 8, 125.

\title{
Deficiency of factor B of the complement system in sickle cell anaemia
}

\author{
W A WILSON, G R V HUGHES, P J LACHMANN
}

British Medical fournal, 1976, 1, 367-369

\section{Summary}

Factors $B$ and $D$ as well as the total activity of the alternative pathway of complement activation were measured using a functional assay in sera from 29 patients with sickle cell anaemia and 18 normal controls. Total alternative pathway activity was reduced in the patients compared with controls. In patients with abnormally low total alternative pathway activity factor $D$ levels were normal, whereas factor $B$ levels were significantly depressed to a mean level of about half of normal. Regression analysis in patients also showed a significant relation between total alternative pathway activity and factor B levels. A deficiency of factor $B$ is the likely cause

Department of Medicine, University of the West Indies, Jamaica WENDELL A WILSON, MD, MRCP, lecturer

GRAHAM R V HUGHES, MD, MRCP, senior lecturer (present address: Department of Rheumatology, Royal Postgraduate Medical School, London)

MRC Research Group on Serum Complement, Royal Postgraduate Medical School, London W12 0HS

PETER J LACHMANN, SCD, FRCP, professor of the defect in the complement system in patients with sickle cell anaemia. Such a defect may contribute to the excessive proneness of such patients to severe infection.

\section{Introduction}

Bacterial infection accounts for $30-40 \%$ of the mortality in patients with sickle cell anaemia, ${ }^{12}$ the pneumococcus and Gramnegative pyogenic organisms being the commonest pathogens concerned. ${ }^{134} \mathrm{~A}$ possible mechanism for this proneness to severe infection has been suggested by the report of a deficiency in the capacity of serum from patients with sickle cell anaemia to opsonify pneumococci. ${ }^{56}$

Alternative pathway function appears to be more critical than classical pathway function to the bactericidal effect of normal serum, ${ }^{7}$ and the defect in sickle cell sera may result from a selective abnormality of the alternative pathway by which the third component of complement (C3), the essential opsonin, is activated; in these patients opsonification by the classical pathway is normal. ${ }^{6}$ Although their precise interactions are not fully understood the main serum factors that interact to generate $C 3$ convertase by the alternative pathway have been defined: they are properdin, factors B (C3 proactivator or glycine-rich $\beta$-glycoprotein) and D (C3 proactivator convertase), and $\mathrm{Mg}^{++} .^{7-11}$ We assessed total alternative pathway function in patients with sickle cell anaemia and attempted to define the relative contributions of factors $B$ and $D$ to any defects observed. 


\section{Patients and methods}

Twenty-nine Jamaicans with homozygous sickle cell anaemia ( 14 males and 15 females, with a mean age of 21 years) and 18 normal controls ( 9 males and 9 females, with a mean age of 19 years) were studied. All patients with sickle cell anaemia were being followed up at the sickle cell clinic of the University Hospital of the West Indies and no patient had acute complications at the time of the study. The diagnosis of homozygous sickle cell disease was based in all cases on alkaline haemoglobin electrophoresis, a positive sickle test result, and a characteristic blood film. Normal controls were healthy schoolchildren and laboratory personnel with normal haemoglobin and haemoglobin electrophoresis. Blood was drawn and allowed to clot at room temperature, and serum was stored in aliquots at $-70^{\circ} \mathrm{C}$ until immediately before assay. Pooled normal serum was produced by mixing aliquots of each normal control serum.

Assays for factors $\mathrm{B}$ and $\mathrm{D}$ were performed by haemolytic radial diffusion as described by Martin et al. ${ }^{12}$ The plates were of $1.2 \%$ agarose incorporating $0.5 \%$ guinea-pig erythrocytes and $5 \%$ of human serum depleted of factor $B$ or $D$ in phosphate buffered saline $\mathrm{pH} 7 \cdot 2$ containing $10-\mathrm{mM} \mathrm{Mg}^{++}$. Factor $\mathrm{B}$ was depleted from serum by heating at $50^{\circ} \mathrm{C}$ for 15 minutes, factor $\mathrm{D}$ by taking the exclusion peak from Sephadex G75 gel filtration. Total alternative pathway activity was measured on plates as above, except that the factor B or D depleted serum was omitted. Serum samples of $7 \mu \mathrm{l}$ were put into wells in the plates, which were then incubated overnight at $4^{\circ} \mathrm{C}$, followed by one to two hours at $37^{\circ} \mathrm{C}$ for estimating factor $\mathrm{D}$ and three to five hours for estimating total alternative pathway activity. Areas of lysis were measured by planimetry of enlarged images. For dilutions of pooled normal serum areas of lysis were linearly related to the log of the reciprocal of the dilution of the serum pool, the mean slope for five assays being 0.7 for factor $B$ (fig 1 ) and 1.1 for total alternative pathway activity. Results were expressed as a percentage of the area of lysis produced by undiluted pooled normal serum. Duplicate assays (on separate plates) were done for total alternative pathway activity on 24 sera and on 12 sera each for factors $B$ and $D$. The average deviation from the mean value for each sample was 5.3\% for total alternative pathway, $5.2 \%$ for factor $B$, and $4.8 \%$ for factor $D$. Statistical significance was assessed by Student's $t$ test.

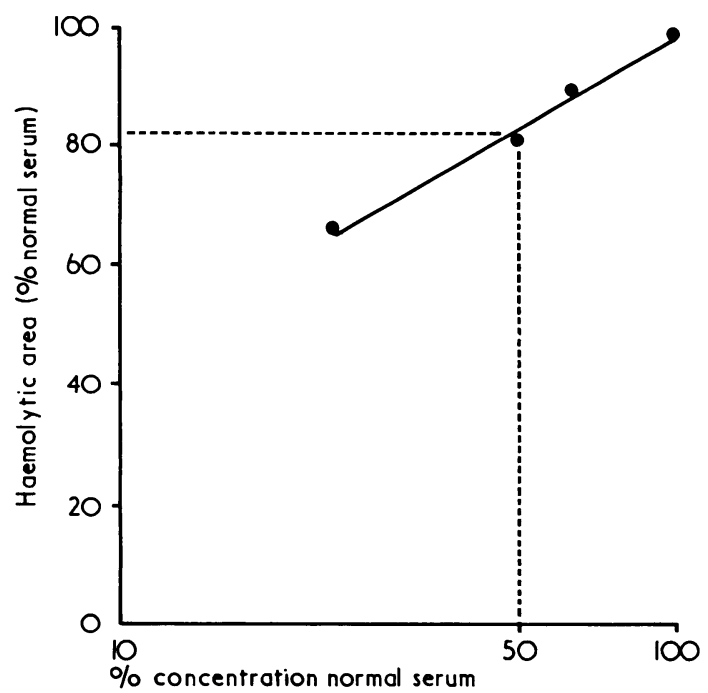

FIG 1-Mean titration curve for pooled normal serum (five assays) for factor B assay. Dotted lines show mean haemolytic area produced by a $50 \%$ dilution of pooled normal serum.

\section{Results}

Total alternative pathway activity was significantly less in sickle cell sera than in control sera (table I). Total alternative pathway activity was below the lower $95 \%$ confidence limit of normal in eight patients (fig 2). Factor B and D levels were not significantly different in normal and patient sera (table I); but in the sera of the eight patients with low total alternative pathway activity (table II) factor $B$ levels were significantly lower than those of normal controls $(P<0.001)$ and those of patients with normal total alternative pathway activity $(P<0.01)$.
TABLE I-Total alternative pathway activity and factors $B$ and $D$ in normal and patient sera. Results are mean $( \pm S D)$ percentages of area of lysis produced by undiluted pooled normal serum

\begin{tabular}{l|c|c|c}
\hline & $\begin{array}{c}\text { Total alternative } \\
\text { pathway activity }\end{array}$ & $\begin{array}{c}\text { Factor } \\
\text { B }\end{array}$ & $\begin{array}{c}\text { Factor } \\
\text { D }\end{array}$ \\
\hline $\begin{array}{l}\text { Normal controls }(n=18) \\
\text { Patients }(\mathrm{n}=29)\end{array}$ & $\begin{array}{c}97 \cdot 4 \pm 8 \cdot 0 \\
89 \cdot 1 \pm 11 \cdot 2^{*}\end{array}$ & $\begin{array}{c}96 \cdot 3 \pm 9 \cdot 3 \\
91.5 \pm 13 \cdot 0\end{array}$ & $\begin{array}{c}96 \cdot 6 \pm 12 \cdot 7 \\
99 \cdot 4 \pm 20 \cdot 0\end{array}$ \\
\hline
\end{tabular}

$* \mathbf{P}=0.005$

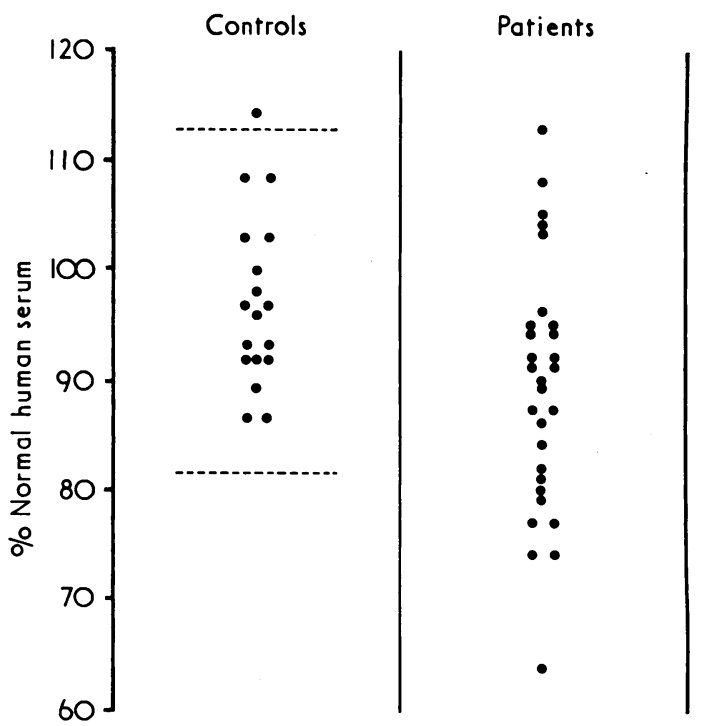

FIG 2-Total alternative pathway activity expressed as haemolytic area ( $\%$ pooled normal serum) in patients and controls. Dotted lines represent $95 \%$ confidence limits.

TABLE II-Factors $B$ and $D$ in patients according to their alternative pathway activity. Results are mean $( \pm S D)$ percentages of lysis produced by undiluted pooled normal serum

\begin{tabular}{|c|c|c|}
\hline & Factor B & Factor D \\
\hline $\begin{array}{l}\text { Patients with low alternative activity }(\mathrm{n}=8) \\
\text { Patients with normal alternative pathway activity } \\
(\mathrm{n}=21)\end{array}$ & $\begin{array}{l}81 \cdot 0 \pm 12 \cdot 2 \\
95 \cdot 4 \pm 11 \cdot 3\end{array}$ & $\begin{array}{r}94 \cdot 4 \pm 15 \cdot 5 \\
100 \cdot 2 \pm 21 \cdot 9\end{array}$ \\
\hline
\end{tabular}

The mean level of this depression was about $50 \%$ of functional activity (see fig 1 ). Though factor $\mathrm{D}$ levels were also lowest in patients with decreased alternative pathway activity they were not significantly lower than levels in either the control $(\mathbf{P}>0.6)$ or the other patients $(\mathrm{P}>0.4)$ (table II). Total alternative pathway activity in the 29 patients was also significantly related to factor $B$ levels (linear regression correlation coefficient $r=0.57 ; P<0.05)$ but not to factor $\mathrm{D}$ levels $(r=0.26$; $\mathrm{P}>0.05)$.

\section{Discussion}

It is apparent from this study that low alternative pathway activity is associated with reduced levels of factor B in patients with sickle cell anaemia and that levels of factor D are normal in such patients. It is not possible to measure properdin functionally in a similar system, so any role that properdin may have in producing the defect remains uncertain.

The alternative pathway of complement activation involves activation of properdin by zymosan, bacterial lipopolysaccharides, or IgA ${ }^{1314}$ in the presence of $\mathrm{C} 3$ and factor $\mathrm{D}$; this leads to the cleavage of factor $\mathrm{B}$ into two fragments, one of which complexes with preformed $\mathrm{C} 3 \mathrm{~b}$ to form a C3 convertase. ${ }^{7-11}$ Activation of $\mathrm{C} 3$ by either the classical or the alternative pathway produces its derivative $\mathrm{C} 3 \mathrm{~b}$, which can trigger a feedback amplification system in which more C3 convertase is produced 
by the interaction of $\mathrm{C} 3 \mathrm{~b}$ with factors $\mathrm{B}$ and $\mathrm{D}$ in the presence of $\mathrm{Mg}^{++} .{ }^{15}$ Factor $\mathrm{B}$ is consumed not only in the alternative pathway but also in the C $3 b$ feedback system, whereas factor $D$ is probably not significantly consumed in either. A functional deficiency of factor $B$ of the degree we have shown in patients with sickle cell anaemia could therefore restrict both alternative pathway and C3b feedback activity.

This deficiency may be an important limiting factor in the generation of $\mathrm{C} 3 \mathrm{~b}$, and thus in opsonification, and may have an importation bearing on the susceptibility of patients with sickle cell anaemia to infection. Reduced levels of factor B are compatible with its defective synthesis, excessive degradation, perhaps by chronic activation of the pathways, or possibly inhibition. The restoration of opsonification by sera of patients with sickle cell anaemia to normal by the addition of normal serum $^{6}$ makes the last possibility the least likely. Further studies are needed to distinguish between these possibilities and to clarify the relation between this deficiency and other features of the disease.

This work was supported by the Wellcome Trust, and also by Merck, Sharp and Dohme (WI). We thank Miss D Grennan and Mr G Frampton for technical help, Drs M Hobart and L Halbwachs for their advice, and Dr G Serjeant and Dr D King for their help.
Requests for reprints should be addressed to G R V H.

\section{References}

${ }^{1}$ Seeler, R A, Metzger, W, and Mufson, M A, American fournal of Diseases of Childhood, 1972, 123, 8.

2 Konotey-Ahulu, F I D, Lancet, 1971, 2, 1255.

${ }^{3}$ Robinson, M G, and Watson, R J, New England fournal of Medicine, 1966, 274, 1006.

${ }^{4}$ Eeckles, R, Gatti, F, and Renoirte, A M, Nature, 1967, 216, 382

5 Winkelstein, J A, and Drachmann, R H, New England fournal of Medicine, $1968,279,459$.

${ }^{6}$ Johnson, R B, Newman, S L, and Struth, A G, New England fournal of Medicine, 1973, 288, 803.

${ }^{7}$ Gotze, O, and Muller-Eberhard, H J, fournal of Experimental Medicine, 1971, 134, suppl 2, p 90.

8 Fearon, D T, Austen, K F, and Ruddy, S, fournal of Experimental Medicine, 1974, 139, 355.

${ }^{9}$ Muller-Eberhard, H J, and Gotze, O, fournal of Experimental Medicine, $1972,135,1003$.

${ }^{10}$ Goodkofsky, I, and Lepow, I H, fournal of Immunology, 1971, 107, 1200.

${ }^{11}$ Fearon, D T, Austen, K F, and Ruddy, S, fournal of Experimental Medicine, 1973, 138, 1305.

${ }^{12}$ Martin, A, et al, Immunochemistry, in press.

${ }^{13}$ Pillemer, L, Blum, L, and Lepow, I H, Science, 1954, 120, 279.

${ }^{14}$ Soter, N A, Austen, K F, and Gigli, I, fournal of Investigative Dermatology, 1974, 63, 219.

${ }^{15}$ Nicol, P A, and Lachmann, P J, Immunology, 1973, 24, 259.

\title{
Autologous immune complex nephritis associated with sickle cell trait: Diagnosis of the haemoglobinopathy after renal structural and immunological studies
}

\author{
TAKESHI OZAWA， MYRON F MASS， STEPHEN GUGGENHEIM， JOSE STRAUSS, \\ RAWLE M MCINTOSH
}

British Medical fournal, 1976, 1, 369-371

\section{Summary}

A renal tubular epithelial antigen (RTE)-anti-RTE autologous immune complex nephritis associated with sickle cell anaemia (SS) has been reported, but immune complex nephritis has never been described in patients with sickle cell trait (SA). During investigation of a child with "asymptomatic proteinuria" cryoprecipitable complexes of RTE-anti-RTE were detected in the seru m and granular deposits of RTE, immunoglobulins, and complement localised on the glomerular basement membranes. Morphological and ultrastructural studies showed increased mesangial matrix, sickled red blood cells in the glomeruli and vessels, and tubular and interstitial abnormalities. These findings prompted haemoglobin electrophoretic studies, which showed previously undiagnosed haemoglobin $\mathrm{SA}$ in this patient

University of Colorado Medical Centre, Denver, Colorado 8022 TAKESHI OZAWA, MD, fellow in nephrology

MYRON F MASS, MD, fellow in clinical immunology

STEPHEN GUGGENHEIM, MD, assistant professor of medicine and pathology

RAWLE M MCINTOSH, MD, professor of paediatrics and medicine

Department of Paediatrics, University of Miami School of Medicine, Miami, Florida

JOSE STRAUSS, MD, professor of paediatrics and her family. These observations suggest that nephritis mediated by similar immunopathogenic mechanisms may be associated with SS and SA haemoglobinopathy. Under some conditions patients with sickle cell trait may experience haemodynamic and oxygenation abnormalities, which may be aetiological factors in the immune complex nephritis associated with SS disease.

\section{Introduction}

Various renal abnormalities have occurred in association with sickle cell (SS) disease. ${ }^{1-3}$ Recently we reported an immune deposit nephropathy associated with sickle cell disease ${ }^{4}$ and showed an autologous immune complex pathogenesis secondary to glomerular deposition of circulating complexes of renal tubular epithelial antigen (RTE) and antibody in nephritis associated with this disease. ${ }^{6} 7$ Although haematuria, tubular defects, and even the nephrotic syndrome have been reported with sickle cell trait (SA), ${ }^{2}{ }^{8} 9$ an immune deposit glomerulonephritis has not been reported. We report here a patient with proteinuria in whom the localisation of glomerular RTE in association with immunoglobulins and complement, the renal histological findings, and the detection of serum cryoproteins containing RTE and RTE antibody led to the diagnosis of sickle cell trait.

\section{Case Report}

On routine screening of her family because her sister had membranous nephropathy associated with chronic hepatitis B antigen- 